\title{
Model Quantum Tipe VAK Berbasis Penilaian Portofolio Meningkatkan Hasil Belajar IPA
}

\author{
Ni Luh Putu Tatwi Utaminingsih", Desak Putu Parmiti', I Gede Astawan² \\ ${ }^{123}$ Pendidikan Guru Sekolah Dasar, Universitas Pendidikan Ganesha \\ Singaraja, Indonesia
}

e-mail: tatwiu812@gmail.com,dskpt parmiti@yahoo.co.id, igedeastawan@yahoo.com

\begin{abstract}
Abstrak
Rendahnya hasil belajar kognitif IPA disebabkan oleh kebiasaan siswa yang cenderung menghafal dan kurangnya guru melakukan umpan balik serta kurang melakukan penilaian proses. Dari permasalahan tersebut maka tujuan penelitian ini untuk mengetahui pengaruh model pembelajaran quantum tipe visual, auditori dan kinestetik (VAK) berbasis penilaian portofolio terhadap hasil belajar IPA. Jenis penelitian ini adalah kuasi eksperimen dengan rancangan non equivalent posttest only group. Populasi pada penelitian ini adalah siswa kelas IV SD dengan jumlah 157 orang siswa. Jumlah sampel pada penelitian ini yaitu 61 siswa yang ditentukan dengan teknik cluster sampling. Data hasil belajar IPA dikumpulkan dengan instrumen tes pilihan ganda. Teknik analisis data yang digunakan adalah uji-t sampel independent. Berdasarkan analisis data terungkap bahwa thitung yang diperoleh lebih kecil dari 0,05 yaitu 0,001. Berdasarkan hal tersebut dapat disimpulan bahwa model pembelajaran quantum tipe VAK berbasis penilaian portofolio berpengaruh terhadap hasil belajar IPA siswa kelas IV SD.
\end{abstract}

Kata kunci: model quantum, VAK, penilaian portofolio

\begin{abstract}
The low cognitive learning outcomes of science are caused by the habits of students who tend to memorize and the lack of teachers doing feedback and not doing the assessment process. From these problems, the purpose of this study was to determine the effect of visual, auditory and kinesthetic type quantum learning models (VAK) based on portfolio assessment on the learning outcomes of Natural Sciences. This type of research is a quasi-experimental design with a non equivalent posttest only group. The population in this study was class IV elementary school students with a total of 157 students. The number of samples in this study were 61 students who were determined by cluster sampling techniques. Science learning outcomes data were collected with a multiple choice test instrument. The data analysis technique used is independent sample t-test. Based on data analysis, it was revealed that the t count obtained was smaller than 0.05 , which was 0.001 . Based on this it can be concluded that the VAK type quantum learning model based on portfolio assessment has an effect on the learning outcomes of science students in grade IV elementary school.
\end{abstract}

Keywords: quantum models, VAK, portfolio assessment

\footnotetext{
*Corresponding author.

Received 20 April 2020, Accepted 20 Juni 2020; Available online 5 Juli 2020 (C) 2020 MI All Rights Reserved
} 


\section{Pendahuluan}

Sebagai Negara berkembang masih mempunyai tugas penting dalam memajukan Sumber Daya Manusia (SDM). Hal ini juga sejalan dengan cita-cita bangsa Indonesia yang tercantum dalam UUD 1945 pada alenia keempat yaitu mencerdaskan kehidupan bangsa. Untuk mewujudkannya, Pemerintah telah membentuk UU Nomor 20 Tahun 2003 tentang sistem Pendidikan Nasional yang menyatakan tujuan pendidikan nasional adalah menumbuhkan dan melatih watak bangsa yang bermartabat sehingga menghasilkan potensi siswa menjadi manusia yang beriman dan bertaqwa kepada Tuhan Yang Maha Esa, berakhlak mulia, sehat, berilmu, cakap, kreatif, mandiri, dan menjadi warga negara yang demokratis serta bertanggung jawab. Pendidikan mempunyai peranan dalam meningkatan kualitas suatu bangsa. Untuk mencapai tujuan pendidikan nasional, maka ditetapkan beberapa mata pelajaran pada pendidikan dasar khususnya di SD yang diatur dalam Undang-Undang Nomor 20 Tahun 2003, Bab 10 Pasal 37 ayat 1 mengenai sepuluh mata pelajaran yang wajib dicantumkan dalam kurikulum pendidikan dasar pada tingkat SD yaitu salah satunya adalah mata pelajaran IPA. Pembelajaran IPA dapat menumbuhkan peserta didik berpengetahuan, memiliki keterampilan dan menguasai sikap ilmiah sejak usia SD.

IPA adalah pembelajaran yang melakukan kegiatan pengamatan tentang gejala alam, yang selanjutnya harus dianalisis dan disimpulkan sebagai produk (Sulthon, 2016).. Pembelajaran yang berhubungan dengan alam, mencari tahu tentang alam merupakan proses dari pembelajaran IPA. Namun, IPA tidak hanya pengetahuan berupa fakta-fakta, konsep dan prinsip saja, tetapi proses penemuan (Muna, 2017). Pembelajaran IPA sangat baik dibelajarkan sejak usia SD untuk menumbuhkan peserta didik berpengetahuan, memiliki keterampilan dan menguasai sikap ilmiah. Hal ini akan terjadi apabila pola pembelajaran yang diberikan kepada siswa sesuai. Namun, jika pola pembelajarannya hanya dalam bentuk memberikan informasi, maka siswa akan menghandalkan kemampuan menghafalnya. Dalam proses pembelajaran IPA perlu menggunakan penilaian, karena pola penilaian yang baik akan dapat memberikan hasil yang positif terhadap proses pembelajaran dan berpengaruh terhadap hasil belajar siswa (Muna, 2017). Komponen yang terpenting pada saat proses pembelajaran yaitu penilaian. Kusnandar berpendapat bahwa yang dapat memberikan informasi akurat mengenai perkembangan siswa dan kualitas pembelajaran siswa adalah penilaian hasil belajar (dalam Enggarwati, 2015). Berdasarkan penilaian nampak proses pembelajaran IPA diatas belum secara maksimal tercapai.

Tujuan IPA yang belum maksimal dicapai dapat dilihat dari hasil PISA (The Programme for International Student Assessment). Performa peserta didik Indonesia dalam menyelesaikan soal-soal PISA tergolong masih rendah pada Tahun 2018. Pada Tahun 2015, Indonesia mendapat peringkat 62, 61, dan 63 dari 69 Negara untuk Sains (IPA), membaca, dan matematika. Bahkan dari pertama kali Indonesia bergabung dalam PISA yaitu Tahun 2000, peringkat Indonesia selalu dibawah dan sedikit perubahan dari hasil tes yang sebelumnya (Pratiwi, 2019). Sedangkan pada Tahun 2018 performa Indonesia mendapat peringkat 71 (Sains), 74 (membaca), dan 73 (matematika) dari 79 Negara. Skor Bidang Sains dari Tahun ke Tahun tidak mengalami kenaikan yang signifikan, bahkan pada Tahun 2018 mengalami penurunan dari skor performa tahun 2015 yaitu dari skor 403 turun menjadi 396 (OECD, 2018). Berdasarkan hasil PISA menunjukkan perlunya Indonesia memperbaiki sistem pendidikan dalam meningkatkan hasil belajar IPA. Hal ini disebabkan oleh proses pembelajaran yang belum sesuai dengan siswa. Siswa kurang aktif pada saat proses pembelajaran dilakukan, hal tersebut menunjukkan bahwa, keingintahuan siswa terhadap materi pembelajaran IPA kurang (Arini, N. K. A. D., dkk., 2020). Hujaemah, E., dkk (2019) dalam penelitiannya menyatakan metode pembelajaran yang paling sering guru gunakan pada saat proses pembelajaran yaitu metode ceramah. Penggunaan metode ceramah menyebabkan kejenuhan, apabila dilakukan secara terus menerus maka akan berimbas pada hasil belajar siswa. Mata pelajaran IPA sebagian besar dianggap sulit oleh peserta 
didik, anggapan tersebut dibuktikan dari perolehan hasil belajar kognitif IPA siswa (Parwati, I. A. K. C., dkk., 2018)

Pada saat dilakukan pengambilan data awal yaitu wawancara dengan Wali kelas IV SD di Gugus VI Kecamatan Buleleng pada tanggal 17-30 Oktober 2019, ditemukan hal yang sama bahwa, 1) keaktifan saat proses pembelajaran kurang ditunjukkan oleh siswa karena beberapa siswa yang belum dapat membaca dan guru sulit menyesuaikan kemampuan siswa yang lamban belajar, 2) siswa mudah lupa dengan materi yang diajarkan karena siswa cenderung menghafal materi dan di sekolah media yang tersedia terbatas. Setelah dilakukan wawancara, pada tanggal 17-30 Oktober 2019 dilakukan observasi pada saat proses pembelajaran, ditemukan bahwa 1) pelaksanaan proses pembelajaran masih berpusat pada guru sehingga partisipasi siswa dalam pembelajaran belum efektif, 2) perhatian siswa terhadap guru kurang, karena guru jarang melakukan penilaian proses disetiap proses pembelajaran dan tugas-tugas yang diberikan belum ada umpan balik, 3) guru jarang menggunakan model pembelajaran sehingga membuat suasana kelas kurang menyenangkan. Hal ini terjadi karena dirasa waktu pembelajaran akan efektif apabila disampaikan oleh guru atau teacher center.

Pencatatan dokumen dilakukan untuk melengkapi hasil observasi dan wawancara pembelajaran di kelas. Pada pencatatan dokumen dilihat dari hasil belajar kognitif IPA ditemukan masih rendah. Rendahnya hasil belajar (kognitif) IPA ditunjukkan dengan pencatatan dokumen mengenai Penilaian Tengah Semester (PTS) IPA siswa kelas IV pada ranah kognitif yang dilakukan pada tanggal 17-30 Oktober 2019 di SD Gugus VI Kecamatan Buleleng. Dengan keseluruhan jumlah siswa kelas IV di Gugus VI Kecamatan Buleleng yaitu 157 siswa, masih terdapat siswa yang belum memenuhi KKM yaitu sebanyak 82 siswa (53 $\%$ ). Hal ini menunjukkan persentase siswa yang belum mencapai KKM tinggi, sehingga hal tersebut merupakan suatu masalah yang harus diatasi. Mengatasi hasil belajar kognitif dapat diatasi dengan menerapkan model pembelajaran yang sesuai dengan karakteristik peserta didik dan menggunakan penilaian yang mengutamakan proses. Sutadi mengatakan proses pembelajaran akan berjalan secara sistematis apabila menggunakan model pembelajaran sebagai pedoman dalam melakukan pembelajaran, karena model pembelajaran terdiri dari kerangka konseptual yang dapat memberikan pembelajaran lebih bermakna (dalam Handini; Gusrayani; Lichteria, 2016). Proses belajar yang bermakna dapat membantu dalam mengingat materi pembelajaran (Handini; Gusrayani; Lichteria, 2016). Penentuan model pembelajaran perlu mempertimbangkan karakteristik peserta didik. Setiap anak memiliki perkembangan yang berbeda-beda. Perbedaan tingkat perkembangan menyebabkan seorang guru harus berhati-hati menggunakan dan memperhatikan tahap karakteristik anak sebelum memberikan label sesuai tahapan anak. Piaget mengemukakan tahapan pada teori perkembangan kognitif bahwa anak diusia SD berada pada tahap operasional konkret (7-11 tahun). Tahapan tersebut menggambarkan bahwa pada usia SD seorang anak membutuhkan objek konkret dan pembelajaran berbasis situasi yang nyata/kebiasaan. Obyek nyata dan situasi pembelajaran yang sesuai dengan keadaan siswa sang penting dipersiapkan bagi guru (Trianingsih, 2018). Model pembelajaran yang dapat mencakup ketiga gaya belajar (visual, auditory dan kinesthetic) yang berbeda adalah model pembelajaran Quantum tipe VAK (visual auditory kinestethic).

Pembelajaran quantum tipe VAK merupakan model yang mengkombinasikan gaya belajar visual, auditori, dan kinestetik untuk menjadikan pembelajaran menyenangkan dan efektif. Menurut Shoimin (2017) model pembelajaran visual, auditory, kinesthetic merupakan model pembelajaran yang mengoptimalkan gaya belajar visual, auditory, dan kinestetik sehingga siswa nyaman dalam proses pembelajaran. Pada penggunaan model quantum tipe VAK saat pembelajaran memiliki kelebihan yaitu dapat mengkaitkan pengalaman siswa dengan menyesuaikan gaya belajar siswa (Parwati, I. A. K. C., dkk., 2018). Hasil belajar adalah kemampuan yang dimiliki siswa setelah menerima pengalaman belajar dari guru (Moedjiono dan Dimyati dalam Indrayani, K. A. A., dkk., 2019). Berdasarkan hal tersebut, pengembangan kinerja di sekolah dan situasi antar pribadi harus memperhitungkan gaya belajar. Untuk menentukan hal tersebut, maka sangat penting memperhatikan modalitas belajar yang ditentukan dengan menggunakan isyarat verbal (visual, auditorial, dan 
kinestetik) agar tidak salah arah (Riyanto, 2012). Dengan demikian peserta didik dapat memahami setiap bidang ilmu pengetahuan salah satunya mata pelajaran IPA.

Beberapa penelitian menyatakan bahwa model quantum tipe VAK memberikan dampak positif terhadap hasil belajar siswa. penelitian yang dilakukan oleh Jannah, M. M., dkk (2019) menunjukkan pemahaman konsep matematika yang menggunakan model quantum tipe VAK memiliki perbedaan dan lebih efektif. Penelitian Jannah menunjukkan bahwa model quantum tipe VAK dapat memberikan kontribusi positif terhadap pemahaman konsep matematis siswa. Penelitian Sudiantini, N. P. A., dkk (2019) menunjukkan bahwa terdapat perbedaan yang signifikan kompetensi PKn siswa yang dibelajarkan dengan model pembelajaran VAK berbasis tri hita karana dengan siswa yang tidak mendapat perlakuan.

Selain gaya belajar yang harus dipertimbangkan guru, untuk memotivasi siswa agar terus ingin belajar, guru juga harus mempertimbangkan situasi psikologi anak tersebut. Teori Erikson memberikan pandangan tentang perkembangan psikososial bahwa manusia senantiasa mengalami perubahan-perubahan sepanjang hidupnya. Anak usia SD pada perkembangan psikososial dikelompokkan ke dalam tahap industry versus inferiority (berkarya versus perasaan rendah diri) (Trianingsih, 2018). Tahap industry versus infeoriority yang dimaksud adalah ketika peserta memiliki usaha memenuhi tugas-tugas dan berkarya (Semiun dalam Trianingsih, 2018). Dan anak akan merasa tidak percaya diri ketika anak tersebut belum mampu mengerjakan tugas seperti temannya (Sunaryo dalam Trianingsih, 2018). Peran guru sangat penting untuk menyikapi hal tersebut untuk menumbuhkan semangat siswa kemampuan siswa, karena akan lebih berbahaya apabila seorang anak timbul rasa tidak percaya dalam dirinya. Untuk menambah motivasi siswa dalam melakukan proses pembelajaran sangat diperlukan bantuan dalam menilai suatu karya siswa yaitu dengan penilaian portofolio. Penilaian portofolio dapat memacu motivasi siswa agar terus berbenah diri dalam mengerjakan tugas-tugas. Pada proses pelaksanaanya penilaian portofolio dilakukan dengan memberikan tugas dengan tujuan tertentu, kemudian guru memberikan penilaian serta umpan balik, sehingga siswa dapat memperbaiki tugas hingga mencapai hasil yang maksimal (Trianto, 2009).

Jika model quantum tipe VAK dipadukan dengan penggunaan penilaian portofolio, maka pembelajaran akan menciptakan situasi siswa yang aktif dan bermakna. Menurut Surapranata \& Hatta (2007) portofolio sebagai alat penilaian berfungsi untuk: a) menunjukkan kemampuan dan perkembangan siswa setelah mengikuti proses pembelajaran, b) sebagai bahan untuk menindaklajuti kegiatan/pekerjaan yang telah dilakukan, sehingga guru dan siswa mengetahui kemampuan yang harus dikembangkan, c) alat untuk mengetahui rasa bertanggung jawab siswa dalam melakukan pekerjaan, memperluas ruang belajar, dan proses pembelajaran yang terus mengalami pembaharuan, memberikan wawasan kepada peserta didik dalam belajar. Berdasarkan deskripsi di atas, maka penelitian ini bertujuan untuk mengetahui pengaruh model quantum tipe VAK berbasis penilaian portofolio terhadap hasil belajar IPA siswa kelas IV SD Gugus VI Kecamatan Buleleng.

\section{Metode}

Terdapat enam SD di Gugus VI Kecamatan Buleleng yang diikutsertakan dalam penelitian ini, yaitu SD Negeri 1 Kampung Baru, SD Negeri 2 Kampung Baru, SD Negeri 3 Kampung Baru, SD Negeri 4 Kampung Baru, SD Negeri 5 Kampung Baru, dan SD Negeri 7 Kampung Baru. Penelitian ini tergolong penelitian quasi experimental design, karena peneliti tidak memungkinkan memilih dan memilah subjek secara individu. Rancangan penelitian yang digunakan adalah non equivalent post-test only control group design yang menggunakan dua kelompok subjek, salah satunya diberikan perlakuan sedangkan yang lainnya tidak diberikan perlakuan (Setyosari, 2016). Rancangan non equivalent post-test only group design disajikan pada Tabel 1. 
Tabel 1 Rancangan Non Equivalent Post-Test Only Group Design

\begin{tabular}{lll}
\hline Kelompok & Perlakuan & Post Test \\
\hline $\mathrm{E}$ & $\mathrm{X}$ & $\mathrm{O}_{1}$ \\
$\mathrm{~K}$ & - & $\mathrm{O}_{2}$ \\
\hline
\end{tabular}

Populasi dalam penelitian ini adalah seluruh siswa kelas IV SD di Gugus VI Kecamatan Buleleng. Kelas yang diikutkan dalam populasi akan diuji kesetaraan terlebih dahulu kemudian dilakukan teknik pengundian. Untuk mengukur kesetaraan dari populasi menggunakan uji analisis varians satu jalur (Anava-A), dengan kriteria pengujian yaitu apabila $f$ hitung lebih kecil dari $f$ tabel berdasarkan taraf signifikansi $5 \%$ maka populasi dinyatakan setara. Pemilihan sampel dilakukan tanpa pengacakan individu, maka penelitian ini menggunakan teknik cluster sampling. Teknik cluster sampling adalah suatu cara pengambilan sampel sumber data yang akan diteliti sangat luas atau berdasarkan daerah populasi yang ditetapkan (Sugiyono, 2009). Sekolah yang keluar sebagai kelompok eksperimen adalah SD Negeri 4 Kampung Baru dengan jumlah siswa 28, sedang sebagai kelompok kontrol yaitu SD Negeri 3 Kampung Baru dengan jumlah siswa 33, sehingga total sampel dalam penelitian ini yaitu 61 siswa.

Pengumpulan data penelitian ini menggunakan instrument tes pilihan ganda. Data yang diperoleh pada penelitian ini dianalisis dengan metode analisis deskriptif dan dilakukan uji prasyarat analisis. Adapun uji prasyarat analisis yang digunakan yaitu uji normalitas sebaran data yaitu menggunakan analisis Kolmogorov-Smirnov dan Shapiro-Wilk dengan kriteria pengujan jika signifikansi Kolmogorov-Smirnov $\geq 0,05$ maka kedua sampel berdistribusi normal, sebaliknya jika signifikansi Kolmogorov-Smirnov $<0,05$ maka kedua sampel tidak normal. Sedangkan dasar pengambilan keputusan untuk teknik analisis Shapiro-Wilk yaitu sebagai berikut, jika nilai Sig. > 0,05, maka data berdistribusi normal, dan jika nilai Sig. < 0,05, maka data tidak berdistribusi normal. Uji prasyarat analisis yaitu uji homogenitas dengan analisis Levene"s Test dengan kriteria pengujian jika signifikansi pada kolom sig $\geq 0,05$ maka kedua kelompok bersifat homogen, dan jika signifikansi $<0,05$ maka kedua kelompok tidak homogen. Setelah uji prasyarat, dilakukan pengujian hipotesis menggunakan uji independen sample t-test (uji-t). Teknik analisis data pada penelitian ini dihitung dengan bantuan SPSS 20.00 for windows.

\section{Hasil dan Pembahasan}

Hasil belajar kognitif IPA didapat dari skor post test kelompok eksperimen dan kelompok kontrol. Berdasarkan analisis deskriptif pada skor post test siswa kelompok eksperimen, didapat mean sebesar 25 , median sebesar 25,5, modus sebesar 26,16 , standar deviasi yang didapat sebesar 2,46 dan varians sebesar 6,099. Pada kelompok kontrol didapat hasil analisis deskriptif yaitu mean sebesar 22,62, median sebesar 22,33, modus sebesar 19,5, varians sebesar 9,12 dan standar deviasi sebesar 3,02. Dari hasil analisis deskriptif pada mean kelompok eksperimen lebih tinggi dari kelompok kontrol dan menunjukkan perbedaan. Berdasarkan pernyataan Degeng bahwa segala dampak yang diakibatkan dapat dijadikan sebagai indikator nilai dari penggunaan suatu model pembelajaran (dalam Zahro, 2018). Oleh karena itu hasil penelitian menggunakan model pembelajaran quantum tipe VAK berbasis penilaian portofolio memberikan peningkatan yang positif terhadap hasil belajar kognitif IPA. Pada hasil uji normalitas data dengan menggunakan teknik analisis Kolmogorov-smirnov diperoleh harga sig untuk kelas eksperimen dan kelas kontrol masing-masing sebesar 0,162 dan 0,195, hasil perhitungan menunjukkan bahwa skor sig lebih besar daripada 0,05 sehingga kedua kelas dinyatakan normal. Sedangkan uji normalitas menggunakan Shapiro-Wilk didapat hasil sig kelompok eksperimen dan kontrol masing-masing sebesar 0,217 dan 0,155, dari hasil perhitungan menunjukkan skor sig lebih besar dari 0,05 maka dapat disimpulkan bahwa skor post test 
kedua kelas normal. Pada uji homogenitas dilakukan dengan teknik statistik Levene's Test, berdasarkan hasil perhitungan diperoleh $\mathrm{F}$ sebesar 2,441, df1 sebesar 1, df2 sebesar 59 dan sig sebesar 0,124 , dari skor sig terlihat bahwa skor sig lebih besar dari 0,05 , sehingga data skor post test dinyatakan homogen.

Uji hipotesis yang digunakan yaitu uji-t. Berdasarkan hasil perhitungan dengan bantuan program SPSS 20.00 for Windows didapat hasil yang disajikan pada Tabel 2 .

Tabel 2 Hasil Uji Hipotesis

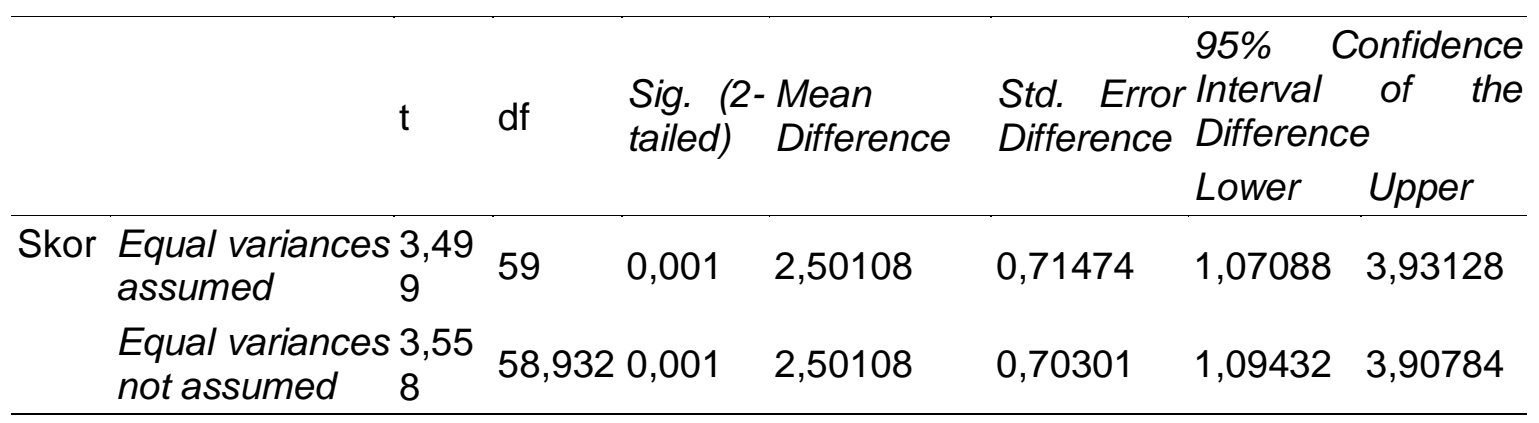

Berdasarkan Tabel 2, skor sig pada kolom sig (2-tailed) dan baris equal variances assumed adalah sebesar 0,001. Skor sig ini lebih kecil dari pada 0,05 maka dapat disimpulkan bahwa terdapat pengaruh yang signifikan hasil belajar kognitif IPA antara kelompok siswa yang dibelajarkan dengan model pembelajaran Quantum tipe VAK berbasis penilaian portofolio dan kelompok siswa yang tidak dibelajarkan dengan model pembelajaran Quantum tipe VAK berbasis penilaian portofolio pada siswa kelas IV SD di Gugus VI Kecamatan Buleleng Tahun Pelajaran 2019/2020.

Pernyataan tersebut sejalan dengan penelitian yang dilaksanakan oleh Elisa, dkk, (2019) yang menunjukkan bahwa terdapat pengaruh model pembelajaran VAK terhadap hasil belajar IPA yang ditunjukkan dengan nilai gain score peserta didik kelompok eksperimen lebih tinggi daripada hasil gain score peserta didik kelompok kontrol. Penelitian dari Alditia, dkk (2016) menyimpulkan bahwa hasil penelitian yang dilakukan menunjukkan adanya perbedaan yang signifikan kelompok eksperimen dengan kelompok kontrol terhadap hasil belajar IPA.

Adanya perbedaan hasil belajar kognitif yang signifikan dikarenakan perbedaan perlakuan antara kelompok kontrol dan kelompok eksperimen. Kelompok eksperimen diberikan perlakuan model quantum tipe VAK berbasis penilaian portofolio sedangkan kelompok kontrol tidak diberikan perlakuan. Dari hasil menunjukkan bahwa pernyataan Tu'u memang benar, suatu hasil belajar siswa akan dipengaruhi oleh strategi atau model yang digunakan pada saat pembelajaran (dalam Anggis, 2016). Model pembelajaran quantum adalah model multi sensorik yang meminta siswa melibatkan tiga unsur gaya belajar antara lain penglihatan, pendengaran dan gerakan (Huda dalam Khasanah, dkk., 2018). Tiga unsur gaya belajar tersebut memiliki karakternya masing-masing, pada gaya belajar visual menggunakan penglihatanya untuk mengingat atau memahami materi pembelajaran, dalam bentuk sajian warna, potret, hubungan ruang dan sebagainya. Gaya belajar audio memahami atau mengingat sesuatu melalui bunyi dan kata yang diciptakan, dapat dalam bentuk musik, dialog, suara dan sebagainya. Dan gaya belajar kinestetik memahami atau mengingat sesuatu melalui gerakan, tanggapan emosional, kenyamanan fisik dan sebagainya (Riyanto, 2012). Proses pembelajaran VAK merupakan model dengan proses pembelajaran yang memanfaatkan setiap individu dengan maksud agar kebiasaankebiasaan siswa belajar terpenuhi (Rukmana, 2018). Model ini menjadi solusi yang sangat baik, karena dapat meminimalisir kesulitan siswa dalam proses pembelajaran, akibat dari cara atau gaya belajar yang tidak sesuai (Rahayu, dkk., 2017).

Model pembelajaran quantum Tipe VAK pada proses pembelajarannya terdiri dari empat tahap yaitu, tahap persiapan, tahap penyampaian dengan gaya belajar VAK, tahap 
pelatihan dan tahap penampilan hasil dengan paduan penilaian portofolio. Tahap persiapan, guru mengukur pengetahuan awal siswa melalui apersepsi, guru memotivasi siswa dan memberikan pembukaan yang menarik sehingga siswa menjadi fokus dalam mengikuti pelajaran, karena apersepsi yang diberikan menggunakan benda-benda nyata yang sesuai dengan kehidupan siswa sehari-hari. Selain benda siswa juga diberikan video mengenai materi yang akan dipelajari sehingga saat akan melanjutkan pembelajaran timbul pertanyaan dari siswa, serta siswa akan mudah memahami materi yang akan dipelajari. Hal ini senada dengan pendapat Samatowa (2016) tentang beberapa aspek yang harus diperhatikan guru dalam mengajar yaitu salah satunya, pentingnya memahami bahwa saat memulai kegiatan pembelajaran, anak telah memiliki konsepsi, pengetahuan yang relevan dengan apa yang mereka pelajari. Pemahaman pengetahuan pada saat pembelajaran akan berdaya guna untuk membantu anak meraih pengetahuan yang mereka miliki.

Tahap penyampaian, siswa diarahkan menemukan materi pembelajaran melibatkan gaya belajar VAK. Sesuai prinsip model quantum tipe VAK, yaitu segalanya berbicara yang artinya seluruh yang ada di lingkungan sekolah baik ruangan kelas, gesture, kertas yang dibagikan semuanya memberikan pesan tentang belajar (DePorter, 2005). Siswa dapat menggali pengetahuan melalui visual, auditory dan kinestetik, sehingga siswa yang lamban belajar akan teratasi kelemahannya melalui kelebihan masing-masing. Pada tahap ini juga menunjukkan bahwa pada model quantum tipe VAK menerapkan konsep IPA yaitu bukan sekedar hafalan tetapi pelajaran yang memupuk sikap dan keahlian siswa untuk memahami gejala alam yang berbeda-beda yang terjadi di lingkungan mereka (Khairudin dan Soedjono dalam Tias, 2017). Pada penelitian ini guru memberikan materi secara visual dan audio menggunakan gambar yang bergerak melalui video serta menggunakan warna pada power point agar lebih menarik. Guru menerangkan arti-arti dari gambar yang ditampilkan melalui video yang sudah disajikan dan menerangkannya kembali. Senada dengan pendapat Tim Pengembang MKDP Kurikulum dan Pembelajaran (2011) tentang faktor yang mempengaruhi hasil belajar peserta didik yaitu faktor non intelektual salah satunya minat dan motivasi siswa.

Tahap pelatihan, siswa terbentuk dalam beberapa kelompok dan diberikan kesempatan dalam menumbuhkan interaksi sosial antar siswa, pada tahap ini juga siswa dibantu oleh guru mendemonstrasikan pengetahuan yang telah diterima. Pada pembelajaran IPA akan sangat baik apabila siswa dilibatkan secara maksimal sehingga tujuan pembelajaran IPA tercapai. Adapun tujuan pembelajaran IPA yaitu menumbuhkan sikap positif dan rasa keingintahuan, mampu menganalisis keadaan alam sekitar, menemukan solusi masalah dan menentukan keputusan serta mendapat manfaat dari hasil perkembangan pengatahuan dan konsep IPA (Asy'ari dalam Surahman, dkk., 2014). Fase ini siswa juga melakukan pelatihan yang akan dibantu oleh guru menggunakan alat bantu mengajar dan meminta siswa untuk mendemonstrasikannya. Siswa diajak melakukan pengalaman langsung terkait materi pembelajaran, seperti melakukan percobaan. Temuan pada penelitian ini siswa sangat antusias melakukan percobaan suatu konsep misalnya pada materi magnet dan menguji adanya kelistrikan pada suatu benda. Selain itu siswa tidak mudah lupa dengan materi yang telah dipelajari. Sesuai dengan pendapat Leighbody \& Kidds yaitu, apabila keterampilan siswa dilatih secara praktik dan berulang-ulang maka akan dapat menjadi kebiasaan yang otomatis (Nurtanto \& Sofyan, 2015).

Dari tahapan persiapan sampai pelatihan telah memenuhi prinsip-prinsip keberhasilan belajar yaitu perubahan dilakukan secara sadar, setiap proses yang dilakukan siswa sudah mengetahui materi apa yang akan dipelajari melalui apersepsi. Perubahan dalam belajar dilakukan harus mempunyai tujuan, perubahan dalam belajar terjadi secara positif, perubahan yang terjadi berkesinambungan dan adanya perubahan yang permanen dari siswa (Supardi, 2015).

Tahap penampilan hasil, guru memberikan kesempatan kepada siswa untuk sharing, siswa yang ragu-ragu bertanya dibimbing oleh guru untuk bertanya dan memberikan informasi. Jika dalam satu kelompok menemukan kesulitan, maka siswa bertanya pada kelompok lain dan kelompok lain harus memberikan informasi yang telah diketahui. Selain itu, pada fase ini dilakukan penilaian dan evaluasi pada tugas yang telah diselesaikan siswa. 
Temuan pada penelitian ini yaitu, siswa yang pada awalnya hanya bergantung pada anggota kelompok yang mampu, mulai menunjukkan keinginan belajar untuk mempertanggungjawabkan tugas yang dikerjakan secara pribadi. Selanjutnya, setiap siswa menjadi siap dalam mengemukakan tugas yang telah dikerjakan karena guru menerapkan sistem permainan dalam menunjuk siswa untuk menyampaikan hasil diskusi. Pada saat proses mengemukakan pendapat, guru sebelumnya menentukan beberapa siswa yang berbeda pendapat, sehingga dari perbedaan pendapat siswa, akan ditarik suatu simpulan. Pada tahap ini guru juga melakukan penilaian portofolio, siswa diminta memasukkan tugasnya kedalam map yang telah berisikan tugas-tugas siswa, sebelum dimasukkan ke dalam map, guru memeriksa pekerjaan siswa, agar guru dapat mengetahui siswa mana yang belum paham, dan meminta siswa membenahi tugas-tugas yang masih kurang tepat (Trianto, 2009). Berdasarkan latar belakang penilaian, portofolio ditujukan untuk mengukur kemajuan dan memonitor kemajuan kognitif siswa, psikomotor, serta afektif siswa pada bidang studi tertentu dalam bentuk gabungan data hasil kerja siswa yang terstruktur secara runtut dan tersistem yang didapat selama melakukan kegiatan belajar. Penilaian tidak hanya terfokus pada hasil, tetapi cara atau proses siswa belajar (Surapranata \& Hatta, 2007). Pada penelitian ini ditemukan siswa yang pada awalnya tidak bersungguh-sungguh mengerjakan tugas menjadi termotivasi mengerjakan tugas dengan baik.

Berdasarkan langkah-langkah model pembelajaran quantum tipe VAK berbasis penilaian portofolio yang telah dipaparkan, maka langkah-langkah model pembelajaran quantum tipe VAK berbasis penilaian portofolio sangat cocok diterapkan untuk miningkatkan hasil belajar IPA yang dimiliki oleh siswa, karena pembelajaran dengan penerapan model ini mementingkan pengalaman belajar secara langsung dan menyenangkan bagi siswa. Selain itu, pada mata pelajaran IPA sangat cocok menggunakan model ini, karena pendidikan IPA di sekolah dasar merupakan salah satu program pembelajaran yang mengharapkan dapat menjadi wahana bagi siswa untuk mempelajari diri sendiri beserta alam sekitar, serta dapat diterapkan dalam kehidupan sehari-hari. Pada penerapan model ini siswa menjadi termotivasi dalam mengerjakan tugas dengan baik. Selain itu, antusias siswa dalam bersaing dalam mendapatkan nilai yang bagus melalui penilaian portofolio juga sangat menonjol. Melalui penilaian portofolio guru dan siswa memiliki kesempatan untuk mengembangkan kemampuannya, karena penilaian portofolio dapat dijadikan bahan untuk melakukan tindakan atau keputusan dalam proses pembelajaran (Sumardi, 2017).

Adapun kelebihan dari model pembelajaran Quantum tipe VAK menurut Suryadin (2017) yaitu dapat mengaitkan pengalaman siswa dengan bantuan modalitas yang ada pada diri siswa yaitu penglihatan (visual), pendengaran (auditory) dan gerakan tubuh (kinesthetic) dan di akhir pelajaran siswa mendapatkan sebuah penghargaan dari hasil kerjanya yang dapat memacu mental dan memotivasi siswa-siswa yang lain, sehingga pembelajaran dapat lebih bermakna. Hal ini berarti bahwa menggunakan kombinasi modalitas visual, auditori dan kinestetik dalam belajar akan mempermudah siswa dalam menyerap, menyaring dan mengolah informasi yang mereka dapatkan dari proses pembelajaran yang berlangsung. Selain itu, hasil penelitian ini juga didukung oleh hasil penelitian dari Ariastini (2013) yang menunjukkan bahwa hasil penelitian dengan menggunakan model pembelajaran quantum tipe VAK berbasis penilaian portofolio dapat meningkatkan hasil belajar siswa dibandingkan dengan pembelajaran yang tidak menggunakan model pembelajaran quantum tipe VAK berbasis penilaian portofolio. Hal ini karena model pembelajaran quantum tipe VAK Di samping itu, model pembelajaran kuantum tipe VAK, karena tipe VAK (Visual Auditory Kinesthetic) dengan menggunakan penglihatan, pendengaran dan gerakan siswa dapat mempraktikan pengalamannya secara langsung. Dapat menjadikan wahana bagi siswa untuk mempelajari diri sendiri dan alam sekitar. Sehingga dalam pembelajaran siswa lebih mengingat dan memahami apa yang dilihat, didengar dan dilakukannya. Ini mengakibatkan pada hasil belajar IPA yang lebih baik dibandingkan dengan siswa yang diberi pembelajaran konvensional. 
Sesuai dengan penjelasan tersebut, proses pembelajaran yang menerapkan model pembelajaran Quantum tipe VAK memiliki keunggulan dari penelitian-penelitian sebelumnya. Keunggulan tersebut terletak pada penilain portofolio yang dilakukan. Pada penilaian portopolio siswa memiliki jiwa saing yang tinggi agar hasil belajar yang didapat lebih maksimal dari sebelumnya dan dalam penerapan penilaian portofolio motivasi dan semangat siswa mengikuti pembelajaran semakin meningkat. Hal tesebut akan berdampak pada hasil belajar yang dimiliki oleh masing-masing individu.

\section{Simpulan}

Berdasarkan hasil penelitian dan analisis data statistik, maka dapat disimpulkan bahwa terdapat pengaruh yang signifikan hasil belajar kognitif IPA antara kelompok siswa yang dibelajarkan dengan model pembelajaran Quantum tipe VAK berbasis penilaian portofolio dan kelompok siswa yang tidak dibelajarkan dengan model pembelajaran Quantum tipe VAK berbasis penilaian portofolio pada siswa kelas IV SD di Gugus VI Kecamatan Buleleng Tahun Pelajaran 2019/2020.

Saran yang dapat disampaikan berdasarkan penelitian yang dilakukan adalah sebagai berikut. Kepada guru pengajar agar selalu menggunakan model pembelajaran yang inovatif yang sesuai dengan pembelajaran. Dalam hal ini, yaitu model pembelajaran yang membuat siswa mampu memahami materi dan aktif dalam proses pembelajaran IPA di kelas. Bagi kepala sekolah semoga dapat lebih bijaksana dalam menentukan kebijakan terkait proses pembelajaran. Untuk pembaca agar lebih kritis menyikapi penelitian ini, sebab penelitian ini masih kurang dari kata sempurna.

\section{Daftar Pustaka}

Alditia, dkk. (2016). Pengaruh Model Visual, Auditory, Dan Kinesthetic (VAK) Terhadap Hasil Belajar Siswa Pada Materi Sifat-Sifat Cahaya. 1(1), 351-360. https://doi.org/10.23819/pi.v1i1.3041

Anggis, E. V. (2016). Penerapan Model Kooperatif JIGSAW berbasis Lesson Study untuk Meningkatkan Keterampilan Kolaboratif dan Hasil Belajar Kognitif Pendekatan dan Jenis Penelitian. Universitas Wiralodra (Proceeding Biology Education Conference) (ISSN: 2528-5742), Vol 13(1) 2016: 493-497 Penerapan, 13(1), 493-497.

Ariastini, dkk. (2013). Pengaruh Model Pembelajaran Kuantum Tipe VAK (Visual Auditory Kinesthetic) Terhadap Hasil Belajar IPA Siswa Kelas V SD Negeri 2 Sesetan.

Arini, N. K. A. D., dkk. (2020). Korelasi Antara Rasa Ingin Tahu dan Motivasi Belajar dengan Hasil Belajar IPA Siswa Kelas V. MIMBAR ILMU, 25.

DePorter, D. (2005). Quantum Teaching. Bandung: Mizan Media Utama.

Elisa, Triyan Desti, dkk. (2019). Penerapan Model Pembelajaran VAK (Visualization, Auditory, dan Kinestethic) Terhadap Hasil Belajar IPA Peserta Didik Kelas IV SD Negeri 147 Pekanbaru. Jurnal Dinamika Pendidikan Dasar Universitas Riau P-ISSN: 2087412X e-ISSN:2655-870X, 11(1), 19-26.

Enggarwati, N. S. (2015). Kesulitan Guru SD Negeri Glagah dalam Mengimplementasikan Penilaian Autentik pada Kurikulum 2013. Jurnal Pendidikan Guru Sekolah Dasar Universitas Negeri Yogyakarta, 1-7.

Handini; Gusrayani; Lichteria. (2016). Penerapan Model Contextual Teachig and Learning Meningkatkan Hasil Belajar Siswa Kelas IV pada Materi Gaya. Pena IImiah, 1, 451-460.

Hujaemah, E., dkk. (2019). Pengaruh Penerapan Model Snowball Throwing Terhadap Hasil Belajar IPA Di Sekolah Dasar. MUALLIMUNA: Jurnal Madrasah IBTIDAIYAH, 5.

Indrayani, K. A. A., dkk. (2019). Pengaruh Model Quantum Learning Terhadap Peningkatan Hasil Belajar IPA Siswa. JPPSI: Jurnal Pendidikan Dan Pembelajaran Sains Indonesia, 
2.

Jannah, M. M., dkk. (2019). Efektivitas Model Pembelajaran Visualiztion Auditory Kinesthetic (VAK) Terhadap Pemahaman Konsep Matematis Berdasarkan Klasifikasi Self-Efficacy. AKSIOMA: Jurnal Program Studi Pendidikan Matematika, 8.

Khasanah, Latifah, dkk. (2018). Application of Visualization, Auditory, Kinestethic (VAK) Learning Model for Increasing Understanding Energy Concept. Jawa Tengah: Social, Humanities, and Education Studies (SHEs): Conference Series.

Muna, I. A. (2017). Asesmen Portofolio dalam Pembelajaran IPA di Sekolah Dasar. Jurnal Kependidikan Dasar Islam Berbasis Sains, 2.

Nurtanto \& Sofyan. (2015). Implementasi Problem-Based Learning untuk Meningkatkan Hasil Belajar Kognitif, Psikomotor, dan Afektif Siswa di SMK. Jurnal Pendidikan Vokasi, 5.

OECD. (2018). PISA 2018 Insight and Interpretations. Retrieved from https://www.oecd.org/pisa/ PISA 2018 Insights and Interpretations FINAL PDF. ...

Parwati, I. A. K. C., dkk. (2018). Pengaruh Model Pembelajaran VAK (Visual, Auditorial, Kinestetik) Bermediakan Lingkungan Sekolah Terhadap Hasil Belajar IPA. Jurnal Pedagogi Dan Pembelajaran, 1.

Pratiwi, I. (2019). Efek Program PISA Terhadap Kurikulum di Indonesia. Jurnal Pendidikan Dan Kebudayaan (Pusat Penelitian Kebijakan Pendidikan Dan Kebudayaan Badan Penelitian Dan Pengembangan Kementerian Pendidikan Dan Kebudayaan), 4, 51-71.

Rahayu, Megawati, dkk. (2017). Efektivitas Penerapan Model Pembelajaran Vak (Visual, Auditory, Kinesthetic) Terhadap Peningkatan Kemampuan Berpikir Kreatif Siswa Pada Mata Pelajaran Bahasa Indonesia. EDUTCEHNOLOGIA, 3.

Riyanto, Y. (2012). Paradigma Baru Pembelajaran. Jakarta: Prenada Media.

Rukmana, dkk. (2018). Peningkatan Aktivitas dan Hasil Belajar dengan Model Pembelajaran VAK Berbantuan Media Tongkat Tokoh. Https://Ejournal.Undiksha.Ac.Id/Index.Php/IJEE, 2.

Samatowa, U. (2016). Pembelajaran IPA di Sekolah Dasar. Jakarta: PT Indeks.

Setyosari, P. (2016). Metode Penelitian Pendidikan \& Pengembangan (5th ed.; Rendy, ed.). Jakarta: Prebadamedia Group.

Shoimin, A. (2017). 68 Model Pembelajaran Inovatif dalam Kurikulum 2013. Yogyakarta: Arruzz Media.

Sudiantini, N. P. A., dkk. (2019). Pengaruh Model Pembelajaran Visualization, Auditory, Kinesthetic (VAK) Berbasis Tri Hita Karana terhadap Kompetensi Pengetahuan PKn. Jurnal Penelitian Dan Pengembangan Pendidikan, 3.

Sugiyono. (2009). Metode Penelitian Kuantitatif Kualitatif dan R\&D. Bandung: Alfabeta.

Sulthon. (2016). Pembelajaran IPA Yang Efektif dan Menyenangkan Bagi Siswa Madrasah Ibtidaiyah (MI). STAIN Kudus, Jawa Tengah, 4.

Sumardi. (2017). Pengembangan Model Penilaian Portofolio Dalam Pembelajaran Matematika Berbasis Lesson Study Di SMP. Jurnal VARIDIKA, 28.

Supardi. (2015). Penilaian Autentik Pembelajaran Afektif, Kognitif, dan Psikomotor. Jakarta.

Surahman, dkk. (2014). Meningkatkan Hasil Belajar Siswa dalam Pembelajaran IPA Pokok Bahasan Makhluk Hidup dan Proses Kehidupan Melalui Media Gambar Kontekstual pada Siswa Kelas II SD Alkhairaat Towera. Jurnal Kreatif Tadulako ISSN 2354-614X, 3(4), 91-107. 
Surapranata \& Hatta. (2007). Penilaian Portofolio Implementasi Kurikulum2004. Bandung: PT Remaja Rosdakarya.

Tias, I. (2017). Penerapan Model Penemuan Terbimbing untuk Meningkatkan Hasil Belajar IPA Siswa Sekolah Dasar. DWIJACENDEKIA Jurnal Riset Pedagogik P-ISSN 25811843 e-ISSN 2581-1835, 1(1), 50-60.

Tim, P. M. K. dan P. (2011). Kurikulum \& Pembelajaran. Jakarta: PT Raja Grafindo Persada.

Trianingsih, R. (2018). Pengantar Praktik Mendidik Anak Usia Sekolah Dasar. IAIN Syekh Nurjati Cirebon Journals, 3(February), 197-211.

Trianto. (2009). Mendesain Model Pembelajaran Inovatif Progresif. Jakarta.

Undang-Undang Nomor 20 Tahun 2003 tentang Sitem Pendidikan Nasional, 1990. Jakarta.

Undang-Undang Dasar 1945. Jakarta.

Zahro, dkk. (2018). Pengaruh Model Pembelajaran Student Team Achievement Devision (STAD) dan Mind Mapping terhadap Hasil Belajar Siswa Kelas IV Sekolah Dasar. Pendidikan Dasar Dan Pembelajaran, 8 (2), 196. 